\title{
Imbalance between matrix metalloproteinases and their tissue inhibitors in preeclampsia and gestational trophoblastic diseases
}

\author{
Beenish Rahat ${ }^{1}$, Renuka Sharma ${ }^{1}$, Rashmi Bagga ${ }^{2}$, Abid Hamid $^{3}$ and Jyotdeep Kaur ${ }^{1}$ \\ ${ }^{1}$ Department of Biochemistry, Postgraduate Institute of Medical Education and Research, Chandigarh, India, \\ ${ }^{2}$ Department of Obstetrics and Gynecology, Postgraduate Institute of Medical Education and Research, \\ Chandigarh, India and ${ }^{3}$ Cancer Pharmacology Division, CSIR-Indian Institute of Integrative Medicine, \\ Jammu, India
}

Correspondence should be addressed to J Kaur; Email: jyotdeep2001@yahoo.co.in

\begin{abstract}
The invasion cascade exhibited by placental trophoblasts and cancerous cells bears many similarities, and it is attributed to extracellular matrix degradation mediated by matrix metalloproteinases (MMPs). Although proper and controlled invasion by trophoblasts into the maternal uterus is an essential requirement for maintenance of normal pregnancy, any abnormality in this phenomenon results in the development of invasion-related disorders such as gestational trophoblastic diseases (GTDs) and preeclampsia. We studied the epigenetic basis of differential expression of two placental MMPs (MMP2 and MMP9) and tissue inhibitors of metalloproteinases (TIMP2 and TIMP1) during normal gestation and invasion-related disorders, i.e., preeclampsia and GTDs. Our study suggests the association of $\mathrm{H} 3 \mathrm{~K} 9 / 27 \mathrm{me} 3$ with differential expression of these MMPs and their inhibitors, which regulate the placental invasion during normal pregnancy, whereas no role of $\mathrm{CpG}$ methylation was observed in the differential expression of MMPs/TIMPs. Further, development of GTDs was associated with abnormally higher expression of these MMPs and lower levels of their inhibitors, whereas the reverse trends were observed for MMPs and their TIMPs in case of preeclampsia, in association with abnormal changes in $\mathrm{H} 3 \mathrm{~K} 9 / 27 \mathrm{me}$. These results suggest the involvement of higher levels of MMPs in an aggressive invasive behavior depicted by GTDs, whereas lower levels of these MMPs in shallow and poor invasive phenotype associated with preeclampsia. Thus, our study shows the significance of a proper balance regulated by histone trimethylation between differential expression of MMPs and their TIMPs for maintaining normal pregnancy and its deregulation as a contributing factor for pathogenesis of invasive disorders during pregnancy.

Reproduction (2016) 152 11-22
\end{abstract}

\section{Introduction}

To achieve proper attachment of the developing fetus with the maternal uterine wall and to establish an efficient exchange of nutrient and waste material between developing fetus and mother, placental extravillous trophoblasts rapidly proliferate, migrate and invade into myometrium and remodel maternal spiral arteries during implantation (Pijnenborg et al. 1981). This process of placental invasion bears many similarities with the growth of cancer cells, which includes the expression of endopeptidases that degrade extracellular matrix (ECM) and help in tissue remodeling (Soundararajan \& Rao 2004) called matrix metalloproteinases (MMPs). The activities of MMPs are tightly regulated by their proper transcription, translation, activation of the precursor zymogens, and inhibition of their active forms by endogenous tissue inhibitors of MMPs (TIMPs) under physiological conditions (Nagase \& Woessner 1999). TIMPs are known to play regulatory role by controlling the activities of MMPs in tissues (Visse \& Nagase 2003).

Gelatinases, especially $M M P 2$ and $M M P 9$, are known for their important role during pregnancy, being involved in the degradation of collagen IV, which is the prime component of maternal basement membrane (StaunRam \& Shalev 2005). In addition, these MMPs can also degrade other components of ECM-like gelatins, type $\mathrm{V}$ and $\mathrm{XI}$ collagens, and laminin (Nagase et al. 2006). Moreover, the expressions of the mentioned MMPs have been shown to mediate the invasiveness of cultured trophoblasts into the Matrigel (Fisher et al. 1989). Therefore, MMP2 and MMP9 are regarded as the key enzymes during implantation. Although TIMP1 and TIMP2 inhibits the active forms of all MMPs, these preferentially bind to both active and latent forms of MMP9 and MMP2 respectively (Nagase et al. 2006). 
Under normal physiological conditions, MMPs are known to regulate cellular migration, invasion, and angiogenesis during embryonic implantation, whereas under pathological conditions, increased expression and activity of MMPs result in tumor growth, migration, and metastasis, leading to the development of cancer (Corthorn et al. 2007). The controlled expression and a proper balance between MMPs and their inhibitors (TIMPs), which determine the net MMP activity (Seval et al. 2004) and hence regulate the invasive potential of placental trophoblasts, are pivotal for maintaining normal placentation (Staun-Ram \& Shalev 2005). In general, any imbalance in this equilibrium leads to the development of pathological conditions (Verma \& Hansch 2007), and specifically during pregnancy, this imbalance disturbs the trophoblastic invasive cascade, leading to the development of placental disorders such as preeclampsia and gestational trophoblastic diseases (GTDs). These placental disorders are believed to be associated with abnormal invasive potential of placental trophoblasts: preeclampsia is associated with shallow and poor trophoblast invasion into maternal uterus, resulting in the formation of poor connection with maternal arteries (Fisher 2004), whereas uncontrolled and excessive invasion of trophoblasts, which might even be metastatic, leads to the development of GTDs such as hydatidiform mole and choriocarcinoma (Hui et al. 2005). In this context, a previous study reported reduced invasion potential of JAR cells (choriocarcinoma cell line) associated with their decreased secretion of $M M P 2$, upon treatment with preeclamptic serum (Mahameed et al. 2005). Hence, this phenomenon draws a special attention toward studying the expression and regulation of MMPs and their inhibitors during pregnancy. Earlier studies have reported the expressions of MMP2 and MMP9 within the first-trimester placenta (StaunRam \& Shalev 2005), whereas high expression levels of MMP2 and MMP9 have been observed in highly invasive extravillous trophoblasts (Seval et al. 2004). Our previous study (Rahat et al. 2014) and few recent studies (Dokras et al. 2006, Rahnama et al. 2006) have highlighted the importance of epigenetic mechanisms in the regulation of gene expression during placentation. Therefore, we aimed to find the significance of differential mRNA expressions and the epigenetic regulatory mechanisms of MMP2 and
MMP9 and their inhibitors in the development of pathological pregnancies, with reference to normal physiological pregnancies.

\section{Methods}

\section{Study design and sample collection}

Pregnant women diagnosed with normal singleton pregnancy in the first trimester undergoing suction evacuation for medical termination of pregnancy (6-11 weeks, $n=30)$, second trimester undergoing medical termination of pregnancy (16-20 weeks, $n=30$ ), and third trimester (37-40 weeks, $n=30$ ) or pregnancy-related disorders such as preeclampsia (clinical symptoms of $140 / 90 \mathrm{mmHg}$ systolic/diastolic pressure; proteinuria $>300 \mathrm{mg}$ in $24 \mathrm{~h}$, or $1+$ protein on dipstick, $n=30$ ) and hydatidiform mole (diagnosed by ultrasonography during early gestation and further confirmed by histopathology, $n=15$ ) were included in this study. The demographic characteristics of pregnant women included in this study are summarized in Table 1, and the clinical characteristics of preeclamptic women included in this study are summarized in Table 2. There was no significant difference between gestational age of preeclampsia cohort and normal third-trimester cohort. Further, the blood pressure levels of preeclampsia group significantly increased compared with its control group. Written consent was obtained from each subject after clearly informing about the study, and Institute Ethics Committee approved this study. From each subject, $10 \mathrm{~mL}$ maternal peripheral blood was collected before any obstetric procedures and used for the isolation of plasma and maternal blood leukocytes (Chiu et al. 2001). Placental villous tissue samples were collected via caesarean sections in case of pregnant women with normal third-trimester pregnancy or preeclamptic pregnancy, whereas in the case of normal firsttrimester, second-trimester, and molar pregnancies, placental villous tissue samples were collected after elective termination of their pregnancies via suction evacuation or dilation and curettage. All the collected placental samples were immediately processed for isolation of placental villi. The isolated villous tissue was rinsed in sterile ice-cold phosphate-buffered saline and then stored at $-80^{\circ} \mathrm{C}$ for further analysis.

\section{Cell line}

In order to study the level of mRNA expression and the pattern of promoter region methylation for $M M P 2$ and MMP9 and TIMP2 and TIMP1 in choriocarcinoma, we selected JEG-3 cell line, which is a placental choriocarcinoma-derived cell line (Source: American Type Culture Collection). JEG-3 cells

Table 1 Demographic characteristics of the pregnant women included in different groups in the study.

\begin{tabular}{|c|c|c|c|c|}
\hline Study group & $\begin{array}{c}\text { Number of pregnant } \\
\text { women included in } \\
\text { this study }\end{array}$ & $\begin{array}{c}\text { Mean age } \\
\text { in years } \pm S . D .\end{array}$ & $\begin{array}{l}\text { Gestational age } \\
\text { in weeks } \pm \text { S.D. }\end{array}$ & $\begin{array}{l}\text { Gestational age } \\
\text { range in weeks }\end{array}$ \\
\hline Normal first trimester & 30 & $27.9 \pm 3.4$ & $8.2 \pm 1.4$ & $6-11$ \\
\hline Normal second trimester & 30 & $27.6 \pm 3.9$ & $18 \pm 1.6$ & $16-20$ \\
\hline Normal third trimester & 30 & $28 \pm 3.5$ & $38 \pm 0.8$ & $37-40$ \\
\hline Preeclampsia & 30 & $26 \pm 3.3$ & $35.3 \pm 2.5$ & $34-39$ \\
\hline Hydatidiform mole & 15 & $25.1 \pm 2.6$ & $13.6 \pm 2.9$ & $9-18$ \\
\hline
\end{tabular}


Table 2 Clinical characteristics of the preeclamptic women included in this study.

\begin{tabular}{|c|c|c|}
\hline \multirow[b]{2}{*}{ S. no } & \multicolumn{2}{|c|}{ Clinical characteristics of preeclamptic women } \\
\hline & $\begin{array}{c}\text { Proteinuria: as protein } \\
\text { on dipstick }\end{array}$ & $\begin{array}{c}\text { Blood pressure: systolic/ } \\
\text { diastolic pressure in } \mathrm{mmHg}\end{array}$ \\
\hline 1 & $2+$ & $160 / 100$ \\
\hline 2 & $2+$ & $150 / 100$ \\
\hline 3 & $3+$ & 160/90 \\
\hline 4 & $3+$ & $160 / 110$ \\
\hline 5 & $2+$ & $140 / 100$ \\
\hline 6 & $4+$ & $160 / 90$ \\
\hline 7 & $3+$ & $150 / 120$ \\
\hline 8 & $2+$ & $160 / 90$ \\
\hline 9 & $2+$ & $140 / 90$ \\
\hline 10 & $3+$ & $200 / 110$ \\
\hline 11 & $3+$ & $160 / 130$ \\
\hline 12 & $3+$ & $160 / 120$ \\
\hline 13 & $2+$ & $150 / 110$ \\
\hline 14 & $2+$ & $200 / 100$ \\
\hline 15 & $4+$ & $170 / 120$ \\
\hline 16 & $3+$ & $150 / 100$ \\
\hline 17 & $3+$ & $160 / 120$ \\
\hline 18 & $3+$ & $150 / 110$ \\
\hline 19 & $3+$ & $140 / 100$ \\
\hline 20 & $2+$ & $160 / 110$ \\
\hline 21 & $2+$ & $250 / 110$ \\
\hline 22 & $2+$ & $140 / 80$ \\
\hline 23 & $3+$ & 160/110 \\
\hline 24 & $2+$ & 140/106 \\
\hline 25 & $3+$ & $140 / 100$ \\
\hline 26 & $3+$ & 190/110 \\
\hline 27 & $3+$ & $160 / 110$ \\
\hline 28 & $4+$ & $160 / 120$ \\
\hline 29 & $2+$ & $160 / 110$ \\
\hline 30 & $3+$ & $160 / 120$ \\
\hline
\end{tabular}

were maintained in Dulbecco's modified Eagle medium-HG, with $4500 \mathrm{mg} / \mathrm{L}$ glucose supplemented with L-glutamine and sodium bicarbonate ( 3.7 and $2 \mathrm{~g} / \mathrm{L}$ respectively), HEPES $(25 \mathrm{mM})$, and fetal bovine serum $(10 \%)$.

\section{Isolation of cytotrophoblast from first-trimester villi}

Cytotrophoblasts were isolated from first-trimester placentas (6-11 weeks) by enzymatic digestion of first-trimester villi as explained previously (Rahat et al. 2014). Briefly, $2 \mathrm{~g}$ dissected first-trimester villi was subjected to sequential trypsin digestion. After each step, cell debris was removed by passing the cell suspension through pre-equilibrated $60 \mu \mathrm{M}$ mesh and the filtrate with isolated cytotrophoblasts was centrifuged. The obtained cell pellet was resuspended in phosphate-buffered saline and subjected to enrichment on a preformed $10-70 \%$ Percoll gradient at $800 \mathrm{~g}$ for $20 \mathrm{~min}$ at $20^{\circ} \mathrm{C}$. The top cellular layer of mononuclear cells containing cytotrophoblasts was collected and immunopurified for the pure population of cytotrophoblasts by negative selection method using EasySep Human CD45 Depletion Kit and EasySep magnet (STEMCELL Technologies. Vancouver, BC, Canada). The purity of obtained cytotrophoblasts was confirmed by flow cytometry using trophoblast marker cytokeratin-7 (Epitomics, Burlingame, CA, USA), showing $>90 \%$ cells as cytokeratin-7 positive.

\section{Quantitative mRNA estimation}

Total RNA isolated via TRIzol (Ambion, Life Technologies) from placental villous samples, maternal blood leukocytes, and JEG-3 cells was used in mRNA quantification studies. Isolated RNA $(1 \mu \mathrm{g})$ was used in reverse transcription to obtain cDNA using RevertAidTM M-MuLV-RT kit (MBI Fermentas, Life Sciences, Waltham, MA, USA). For endpoint analysis, quantitative reverse transcriptase polymerase chain reaction (qRT-PCR) was carried out in Applied Biosystems real-time PCR system (Life Technologies) on reaction mixture prepared for each sample by mixing SYBR Green master mix $(5 \mu \mathrm{L})$ with $60 \mathrm{ng}$ of the obtained first-strand cDNA template $(1 \mu \mathrm{L}), 500 \mathrm{nM}$ gene-specific primers, and $1.5 \mathrm{mM} \mathrm{MgCl}{ }_{2}$ in a total reaction volume of $10 \mu \mathrm{L}$. PCR product amplification was carried out by initial denaturation at $95^{\circ} \mathrm{C}$ for $10 \mathrm{~min}, 40$ cycles at $95^{\circ} \mathrm{C}$ for $15 \mathrm{~s}$, primer-specific annealing temperature for $1 \mathrm{~min}$, followed by a melt curve of $95^{\circ} \mathrm{C}$ for $10 \mathrm{~s}, 60^{\circ} \mathrm{C}$ for $1 \mathrm{~min}$, and $95^{\circ} \mathrm{C}$ for $15 \mathrm{~s}$. This was followed by normalization of transcript levels to the glyceraldehyde-3-phosphate dehydrogenase $(G A P D H)$, as the cycle threshold $(\mathrm{Ct})$ values were observed to be constant across different trimesters. Relative fold changes in gene expression between different groups were calculated using the comparative threshold cycle or Ct method $(\Delta \Delta \mathrm{CT})$ method (Livak \& Schmittgen 2001). The primers used for mRNA estimation assay are presented in Table 3.

\section{DNA isolation and methylation-sensitive high-resolution melting}

Total genomic DNA isolated by DNA isolation kit (Real Genomics, Real Biotech Corporation, Taipei, Taiwan), from placental villi samples, maternal blood leukocytes, JEG-3 cell line, and circulating DNA isolated by Miniprep DNA isolation kit (Bioserve, Beltsville, MD, USA), from maternal plasma, was used to estimate the promoter region methylation percentage by methylation-sensitive high-resolution melting (MS-HRM) as described previously (Rahat et al. 2014). Briefly, DNA methylation standards were prepared for their use in the estimation of DNA methylation of study samples. Fully methylated DNA (100\% methylated) was prepared by methyltransferase treatment of genomic DNA (M.Sssl enzyme; New England Biolabs, Beverly, MA, USA), whereas 0\% methylation standard was obtained commercially from Qiagen (EpiTect Control DNA). This was followed by bisulfite conversion using EZ DNA Methylation-Gold Kit (Zymo Research, USA), of these methylation standards and $1 \mu \mathrm{g}$ isolated DNA from each subject. The converted DNA was then analyzed for promoter region methylation using gene-specific primers (Table 3). MS-HRM analysis was performed by real-time-based PCR amplification in Applied Biosystems StepOnePlus Real-Time PCR, followed by melt curve analysis. For each assay, a series of different methylation standards ranging from 0 to $100 \%$ CpG methylation were obtained by mixing 100 and $0 \%$ DNA methylation standards in proper proportion. Finally, the raw melt curves were analyzed using MS-HRM software version 3.0.1. from Applied Biosystems to get various methylationpredicting graphs. The data obtained from graphs were used to calculate the exact percentage methylation of unknown samples using Polyfit interpolating function within program MatLab (The MathWorks, Natick, MA, USA). 
Table 3 Primer sequences and their parameters used in the study.

\begin{tabular}{|c|c|c|c|c|}
\hline Assay/Gene & Forward primer $5^{\prime}-3^{\prime}$ & Reverse primer $5^{\prime}-3^{\prime}$ & $\begin{array}{l}\text { Annealing temperature }{ }^{\circ} \mathrm{C} / \\
\text { Amplicon size bp/No. of } \\
\text { CpGs in amplicon* }\end{array}$ & $\begin{array}{l}\text { Genbank accession } \\
\text { number }\end{array}$ \\
\hline \multicolumn{5}{|l|}{ qRT-PCR } \\
\hline MMP2 & AGATCTTCTTCTTCAAGGACCGGTT & GGCTGGTCAGTGGCTTGGGGTA & $64 / 225$ & NM_001127891.2 \\
\hline TIMP2 & СTCGCTGGACGTTGGAGGAAAGAA & ССАTCTGGTACСTGTGGTTCA & $64 / 152$ & NM 003255.4 \\
\hline MMP9 & TTGGTCCACСТGGTTCAАCT & ACGACGTCTTCCAGTACCGA & $64 / 95$ & NM_004994.2 \\
\hline TIMP1 & CATCCTGTTGTTGCTGTGGCTGAT & GTCATCTTGATCTCATAACGCTGG & $64 / 168$ & NG_012533.1 \\
\hline GAPDH & CGACСАСТTTGTCAAGCTCA & AGGGGTCTACATGGCAACTG & $60-65 / 228$ & NM 001256799.2 \\
\hline \multicolumn{5}{|l|}{ MS-HRM } \\
\hline MMP2 & TTGAGTCGGGTAAA TTTTAGGTTAT & ССGССТАATTAAAАССТАСТС & $58 / 84 / 9$ & NG_008989.1 \\
\hline TIMP2 & TAGTAAATATATTCGTAGAAGGTAG & СGСАААСТTТСТСТССТСТTTA & $56 / 148 / 23$ & NC_000017.11 \\
\hline MMP9 & $\begin{array}{l}\text { CGTTGTTGTTTTTTTAGAAGTAATT- } \\
\text { GTTTTTGTT }\end{array}$ & $\begin{array}{l}\text { CGCCCTCAAAAATTTAAAATC- } \\
\text { TACCCAAA }\end{array}$ & $60 / 129 / 9$ & NG_011468.1 \\
\hline $\begin{array}{c}\text { TIMP1 } \\
\text { qChIP-PCR }\end{array}$ & TTTTTAGCGTGGATATTTATTTTTTAG & CCGAACССТАСТTAССТСТАA & $56 / 96 / 7$ & NG_012533.1 \\
\hline MMP2 & CCGGCGTCССТССTAGTAGT & TGTCGСTCTAGGCССTTGAC & $62 / 64$ & NG_008989.1 \\
\hline TIMP2 & GCCAGGCGCACTTAAAATTC & GGGTGGCCTATTGAGAAACTGA & $60 / 71$ & NC_000017.11 \\
\hline MMP9 & ССССТTTACTGСССТGAAGA & AAGGAATGGGCTCTGCTAGG & $62 / 90$ & NG_011468.1 \\
\hline TIMP1 & GGTGGGTGGATGAGTAATGCA & AGCGGGTGCGGAAACC & $60 / 59$ & NG_012533.1 \\
\hline
\end{tabular}

*In case of only MS-HRM assays. qRT-PCR, quantitative Reverse transcriptase polymerase chain reaction; MS-HRM, methylation-sensitive high resolution melting; qChIP, quantitative Chromatin immunoprecipitation assay.

\section{Chromatin immunoprecipitation assay}

The chromatin immunoprecipitation (ChIP) assay was performed only on placental villi samples to estimate the levels of H3K9me3 and H3K27me3 at promoter region of genes as described previously (Rahat et al. 2014). Briefly, $25 \mathrm{mg}$ placental villi were fixed in $1.5 \%$ formaldehyde to cross-link histones with DNA, followed by its disaggregation into single-cell suspension. The cell pellet was resuspended in lysis buffer for sonication in order to shear chromatin, using Bioruptor XL (Diagenode, Liège, Belgium) at 20 pulses of $10 \mathrm{~s}$ each. Sheared chromatin was analyzed on agarose gel to confirm proper shearing of chromatin. The sheared chromatin lysate was then divided into aliquots to be used for input DNA, immunoprecipitation with anti-trimethyl H3-K9/ $\mathrm{K} 27 \mathrm{Ab}$ (Abcam), and normal rabbit immunoglobulin-G in proper proportion. The immunoprecipitated complexes were collected using protein A/G-polyacrylamide beads, followed by reverse cross-linking and proteinase $\mathrm{K}$ treatment. The immunoprecipitated DNA as well as input DNA was isolated by phenol chloroform method and then quantified using specific primers (Table 3) on real-time PCR. ChIP assays for each histone modification specific to a particular gene were done in triplicates. Data were normalized with input DNA and calculated relative to non-specific antibody as fold enrichment.

\section{Statistical methods}

Data were expressed as mean \pm S.E.M. Student's $t$-test was used in order to compare the significance of variance between two groups, whereas ANOVA and then Fisher's post hoc test was used between more than two groups. Further, the correlation between different parameters was estimated by Pearson's correlation analysis. In addition, multiple regression analysis was done in order to study the effect of epigenetic regulatory mechanisms on the mRNA expression. Data were considered statistically significant at $P<0.05$. IBM SPSS statistical program (v.16) and GraphPad Prism (v.5.00.288) were used for statistical analysis.

\section{Results \\ mRNA expression of MMPs and their inhibitors}

Placental trophoblasts are known for their excessive invasive potential invading maternal uterus for proper attachment. This phenomenon requires balanced expression levels of MMPs and their TIMPs. Thus, we analyzed the mRNA expression of MMP2 and MMP9 and their respective inhibitors, i.e., TIMP2 and TIMP1, in normal gestational first-, second-, and third-trimester groups and placental disorders (preeclampsia and molar pregnancy) and JEG-3 cells (choriocarcinoma cell line) (Fig. 1A, B and C). The mRNA expressions of MMP2 and MMP9 and their respective inhibitors TIMP2 and TIMP1 were observed to show a reverse trend with advancing normal gestation. MMP2 expression decreased by 2.5fold $(P<0.01)$ in the second-trimester placental villi and 4.3-fold $(P<0.001)$ in the third-trimester placental villi, whereas TIMP2 expression increased by 9.5 -fold $(P<0.001)$ in the third-trimester placental villi, with respect to the first-trimester placental villi. Similarly, expression of MMP9 decreased by 8.4- and 15.3-fold $(P<0.001)$, respectively, in the second and third trimester relative to the first trimester, whereas that of TIMP1 increased by 2.5 -fold till midgestation $(P<0.001)$, then remained almost constant till term gestation (Fig. 1A). The expression levels of MMP2 and TIMP2 were also observed to show a reverse trend in maternal blood leukocytes showing 2.9- to 3.3-fold decrease after midgestation $(P<0.05)$ and 2.3 -fold $(P<0.01)$ increase in the third trimester, respectively, with reference to 


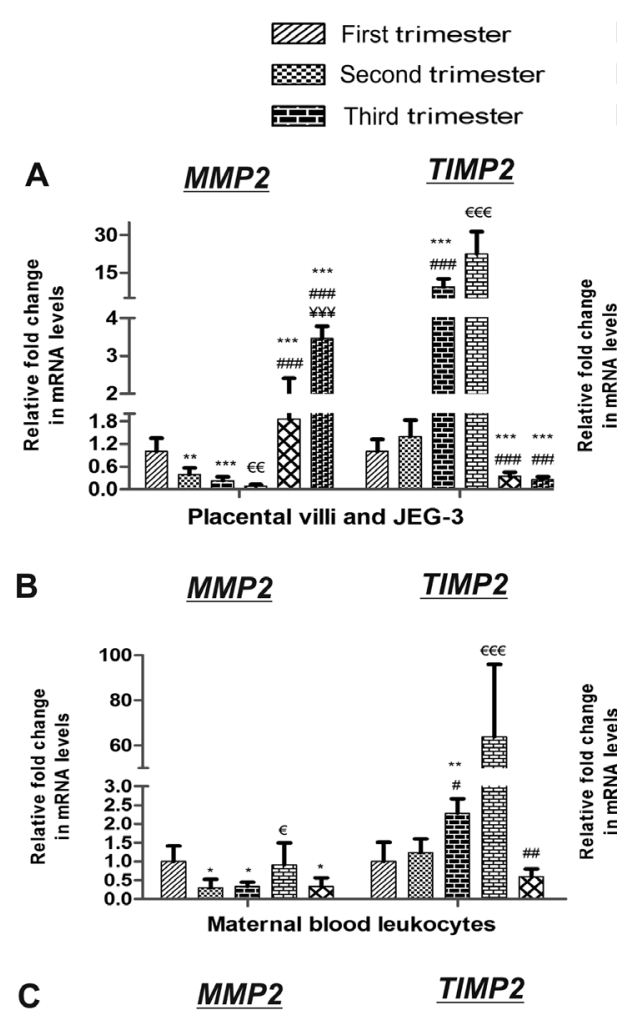

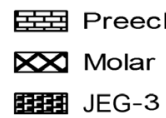

MMPg

MMP9 $\quad$ TIMP1

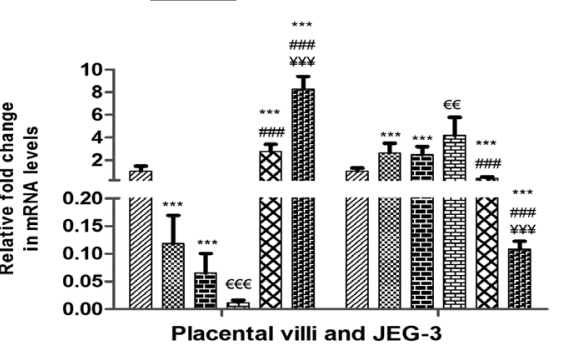

$\underline{\text { MMP9 }} \quad \underline{\text { TIMP1 }}$
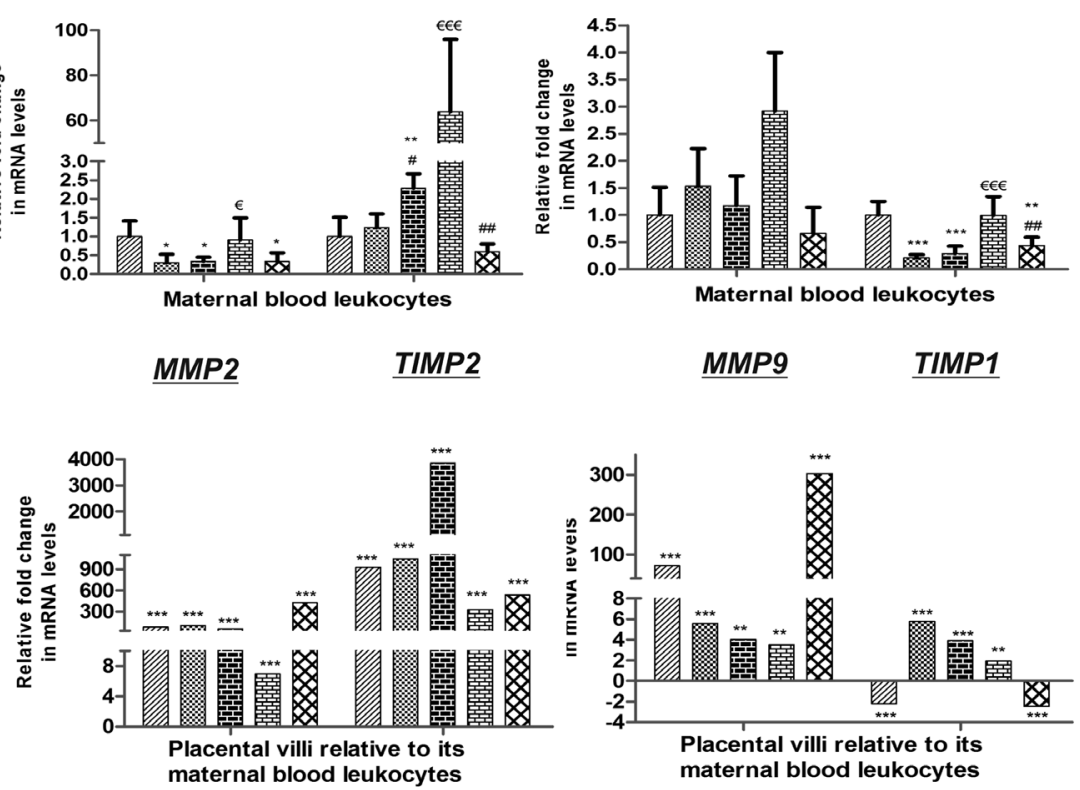

Figure 1 Relative fold change in the mRNA expression of MMPs and TIMPs normalized with GAPDH. Differential mRNA expression among (A) placental villous samples and JEG-3 cells, (B) maternal blood leukocytes $\left({ }^{*} P<0.05,{ }^{* *} P<0.01,{ }^{* * *} P<0.001\right.$ vs first trimester, ${ }^{\sharp} P<0.05,{ }^{\# \#} P<0.01,{ }^{\sharp \#} P<0.001$ vs second trimester, ${ }^{\epsilon} P<0.05,{ }^{\epsilon} P<0.01$,

єє€ $P<0.001$ vs third trimester and $¥ ¥ ¥ P<0.001$ vs molar), and (C) placental villi samples with reference to their corresponding maternal blood leukocytes ${ }^{* *} P<0.01$,

***P$P<0.001)$. The data are presented as mean of the observed fold change \pm S.E.M.; $n=30$ per group. the first trimester. However, expression of MMP9 was observed to show non-significant variation within maternal blood leukocytes, whereas expression of TIMP1 decreased by 3.5- to 4.8-folds after midgestation $(P<0.001)$ (Fig. 1B).

Development of preeclampsia was observed to be associated with a gross decrease in the levels of MMP2 and MMP9 (2.7-fold, $P<0.01$, and 5.6-fold, $P<0.001$, respectively) and increased levels of TIMP2 and TIMP1 (2.4-fold, $P<0.001$, and 1.7-fold, $P<0.01$, respectively) in preeclamptic villi relative to normal term placental villi. Preeclamptic maternal blood leukocytes also showed significantly increased TIMP2 and TIMP1 (28and 3.4-fold, $P<0.001$, respectively) and MMP2 levels (2.7-fold, $P<0.05$ ) with respect to normal third-trimester maternal blood leukocytes.

Development of GTDs demonstrated increased expression in molar villi and JEG-3 cells for MMP2 (1.8- and 3.5-fold, $P<0.001$, respectively) and MMP9 (2.5- and 8.2-fold, $P<0.001$, respectively), whereas the mRNA levels were observed to be decreased in molar villi as well as JEG-3 cells for TIMP2 (2.9- and 3.8-fold, $P<0.001$, respectively) and TIMP1 (2.5- and 9.2-fold, $P<0.001$, respectively), with respect to firsttrimester placental villi. Further, molar maternal blood leukocytes also demonstrated reduced levels of MMP2 (3-fold, $P<0.05)$, TIMP1 (2.3-fold, $P<0.01)$, with respect to first-trimester maternal blood, and TIMP2 (2-fold, $P<0.01)$, with respect to the normal secondtrimester maternal group.

Comparing the mRNA expression of MMP2 and MMP9 and TIMP2 and TIMP1 in placental villi groups with their respective maternal blood leukocytes, it was observed that the expression of these genes were significantly higher in placental villi samples in all groups $(P<0.01$ to $<0.001)$, except for TIMP1 in the first-trimester villi and molar villi, where it was higher in maternal blood $(P<0.001)$ (Fig. 1C).

Pearson's correlation analysis was performed in order to find the correlation between the mRNA expression of these genes during normal gestation (first-, second-, and third-trimester placental villi) and placental 
A MMP2
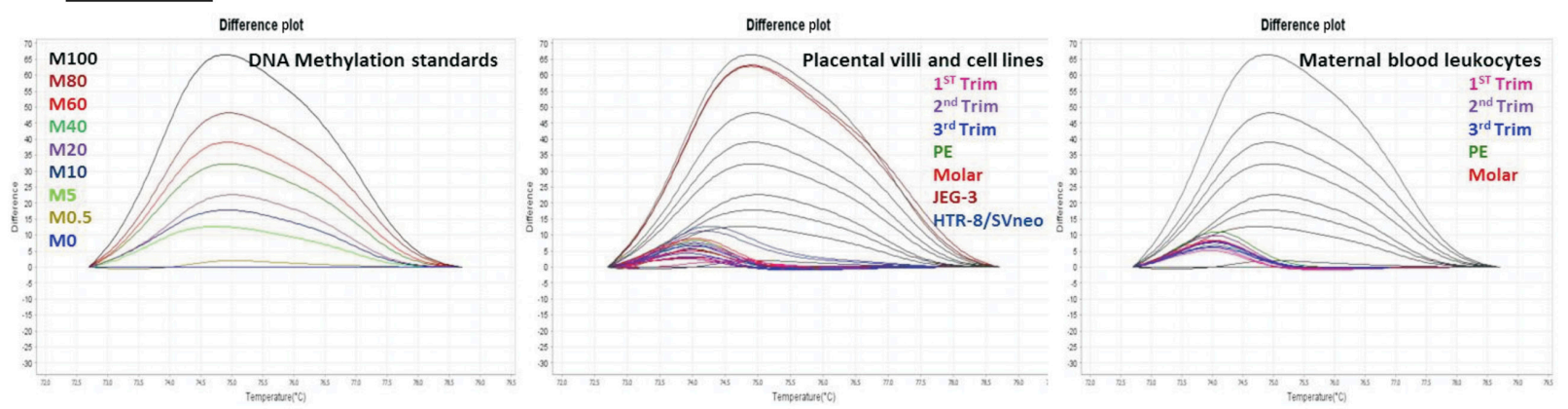

B TIMP2
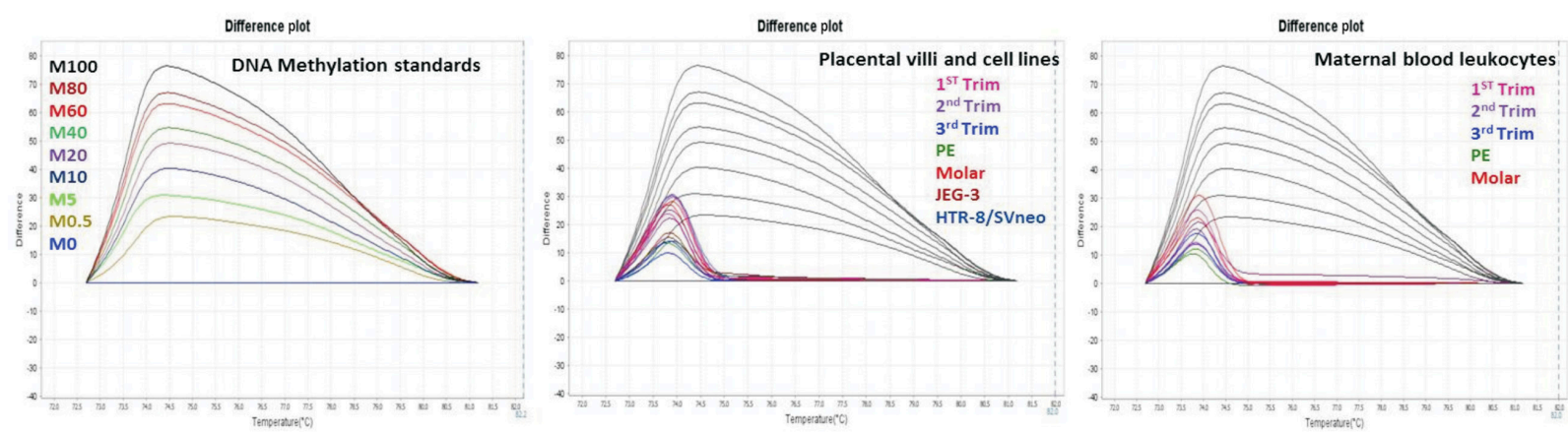

\section{MMP9}
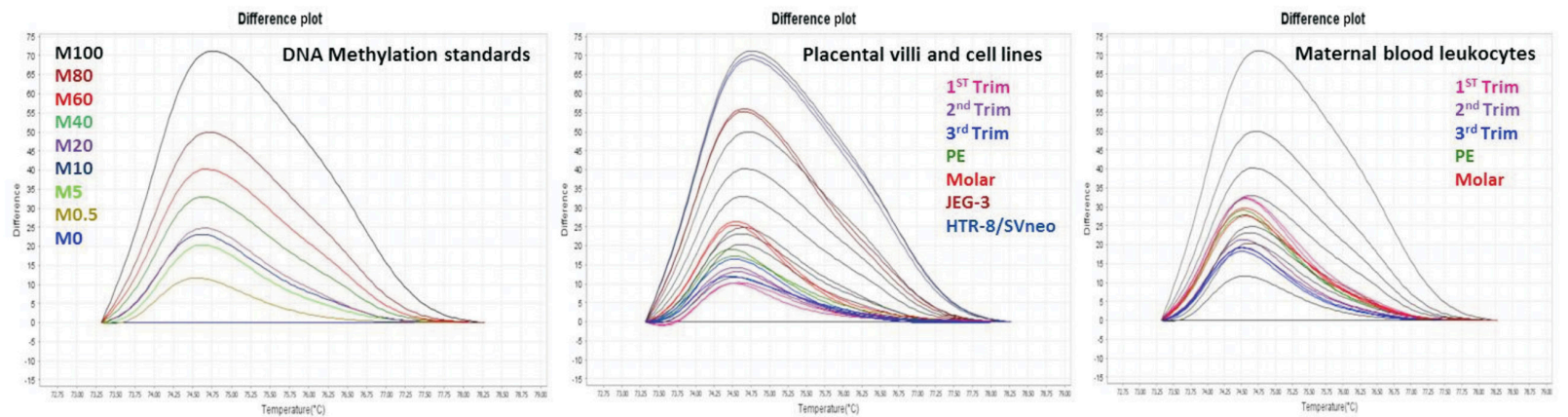

\section{TIMP1}
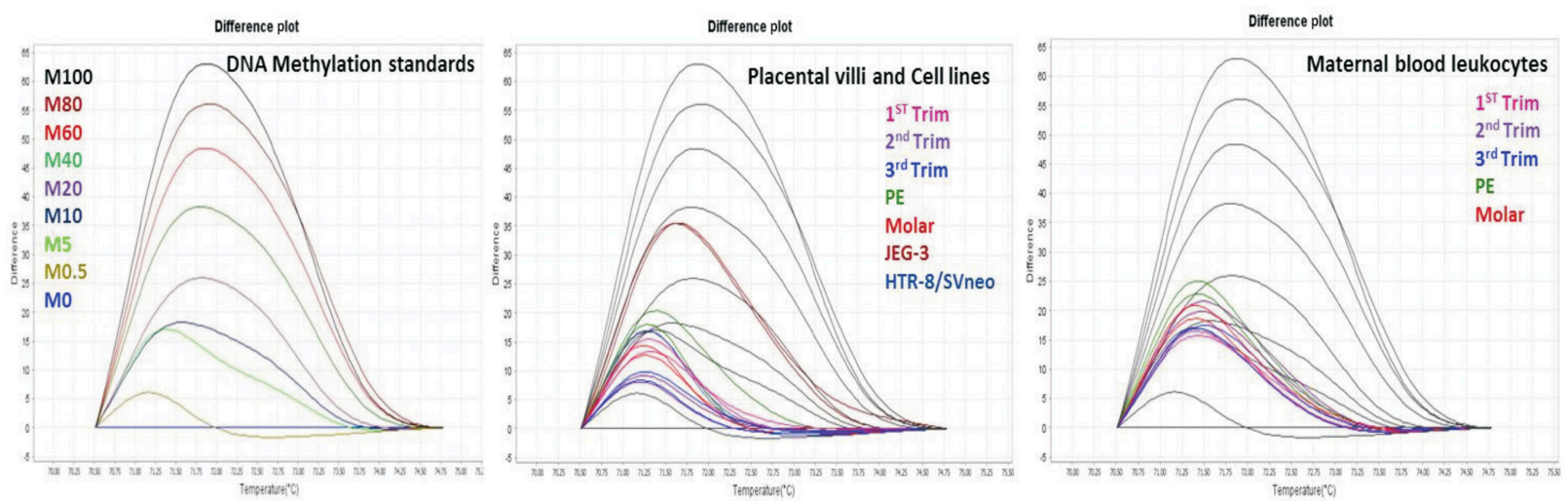

Figure 2 Promoter region DNA methylation as predicted by HRM software. HRM difference plots for (A) MMP2 (B) TIMP2 (C) MMP9, and (D) TIMP1. Each representing three difference plots: first one for methylation standards in different colors (M100 to M0\%, which stands for DNA methylation standards with $100-0 \%$ methylation) normalized to the $0 \%$ methylated standard DNA, second and third difference plots for few selected samples from placental villous groups and cell lines and maternal leukocyte groups represented in different colors and methylated standard curve of M100 to M0\% represented as black curves. Note: "Trim" stands for trimester. 
disorders (preeclamptic and molar villi) in JEG-3 cells, which revealed significantly higher positive correlation between MMP2 vs MMP9 $(r=0.98, P<001)$ and TIMP1 vs TIMP2 ( $r=0.85, P<0.05)$. Further, moderately higher negative correlation was observed between mRNA expressions of $M M P 2$ vs TIMP2 $(r=-0.6)$ and MMP9 vs TIMP1 $(r=-0.73)$ among these groups.

\section{Promoter region DNA methylation of MMPs and their inhibitors}

To elucidate the role of $\mathrm{CpG}$ methylation in mediating the differential expression of MMP2 and MMP9 and their inhibitors TIMP2 and TIMP1 during normal advancing gestation and placental abnormalities, we estimated CpG site DNA methylation at their promoter regions in placental villi samples, maternal blood cells, and placental cell lines. MMP2 and TIMP2 promoter regions (Fig. 2A and $\mathrm{B}$ ) were detected to be either hypomethylated or completely unmethylated with the exception of $M M P 2$ promoter region in JEG-3 cells $(96.8 \pm 1.3 \%$ methylated, $P<0.001)$. However, some variations were detected in the promoter region methylation of MMP9 and TIMP1 (Fig. 2C and D). MMP9 and TIMP1 promoter regions were observed to be hypomethylated with less than $5 \%$ average methylation in normal gestational placental villi groups. Development of preeclampsia and molar pregnancy was observed to be accompanied with increased methylation of MMP9 by 2 -fold $(P<0.05)$ and 3.5 -fold $(P<0.001)$, respectively, in comparison with their respective control groups. Further, similar

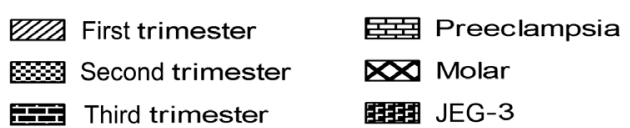

A

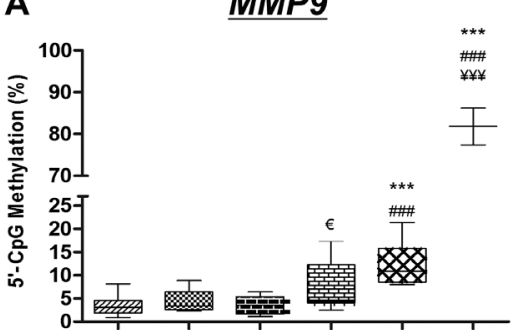

Placental villi and JEG-3

\section{$B$}

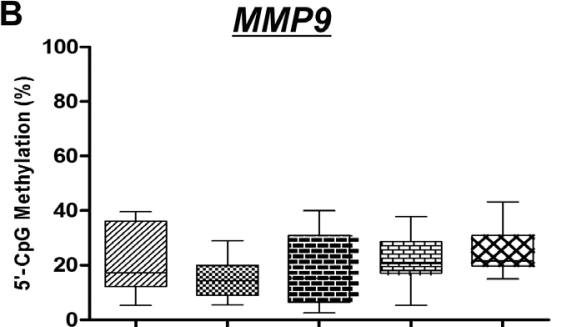

TIMP1

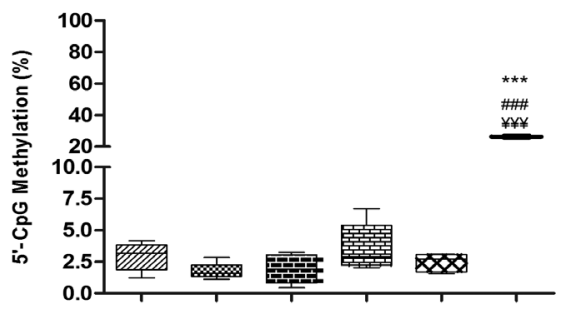

TIMP1

Maternal blood leukocytes

C

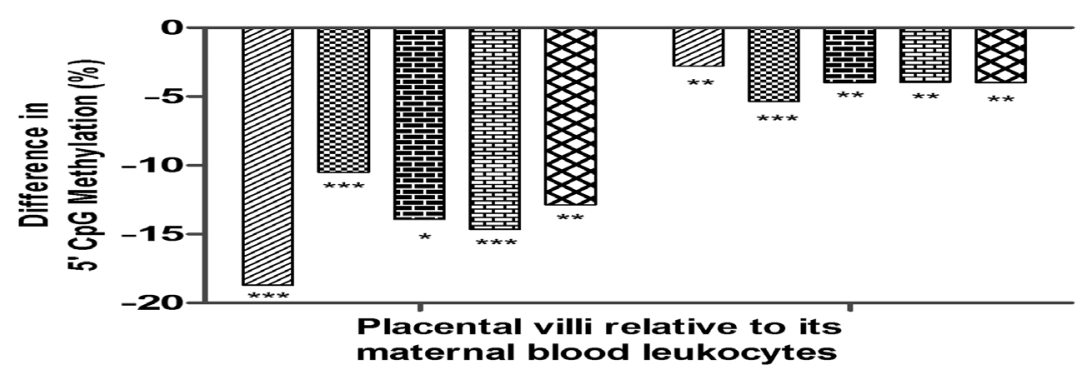

Figure 3 Promoter region DNA methylation for MMP9 and TIMP1. (A) Box-and-whisker plot to show \% CpG methylation among different placental villous samples and JEG-3 cells. (B) Box-and-whisker plot to show \% CpG methylation among maternal blood leukocytes (*** $P<0.001$ vs first trimester, ${ }^{\# \#} P<0.001$ vs second trimester, ${ }^{€} P<0.05$ vs third trimester and $¥ ¥ ¥ P<0.001$ vs molar), and (C) \% CpG methylation in villous samples with reference to their corresponding maternal blood leukocytes $\left({ }^{*} P<0.05,{ }^{*} P<0.01\right.$, $* * * P<0.001) ; n=30$ per group. 
to $M M P 2$, the promoter regions of MMP9 and TIMP1 were also detected to be hypermethylated in JEG-3 cells $(81.6 \pm 6.2 \%$ and $26.3 \pm 1.1 \%$ methylation respectively) (Fig. 3A). Analysis of promoter region methylation of MMP9 and TIMP1 in maternal blood cells revealed non-significant variation between different groups (Fig. 3B), whereas promoter region methylation of MMP9 and TIMP1 was detected to be significantly higher in maternal blood samples relative to their corresponding placental villi groups (Fig. 3C).

Pearson's correlation analysis predicted a positive correlation between mRNA expression and promoter region methylation of $M M P 2(r=0.86, P<0.05)$ and MMP9 $(r=0.97, P<0.01)$ among placental villi groups and JEG-3 cells. In addition, a high positive correlation $(r=0.99, \quad P<0.001) \quad$ was observed among DNA methylation at promoter regions of $M M P 2$ and $M M P 9$ among these groups.

\section{Confirmation of DNA hypomethylation at promoter regions of MMPs and their inhibitors in isolated first-trimester cytotrophoblasts}

In order to confirm our DNA methylation data, we further analyzed the DNA methylation status of MMP2 and MMP9 and TIMP2 and TIMP1 in cytotrophoblasts isolated from first-trimester placenta. Our data from firsttrimester cytotrophoblasts also revealed hypomethylation at the promoter regions of MMP2, TIMP2, MMP9, and TIMP1, with average methylation of $1.1 \pm 0.95$, $0.78 \pm 0.65,2.16 \pm 1.56$, and $4.9 \pm 2.12 \%$, respectively, in cytotrophoblasts, thus confirming no role of DNA methylation in regulating the differential expression of these MMPs and TIMPs. The methylation levels of these genes in cytotrophoblasts and first-trimester villi samples are presented in Fig. 4.

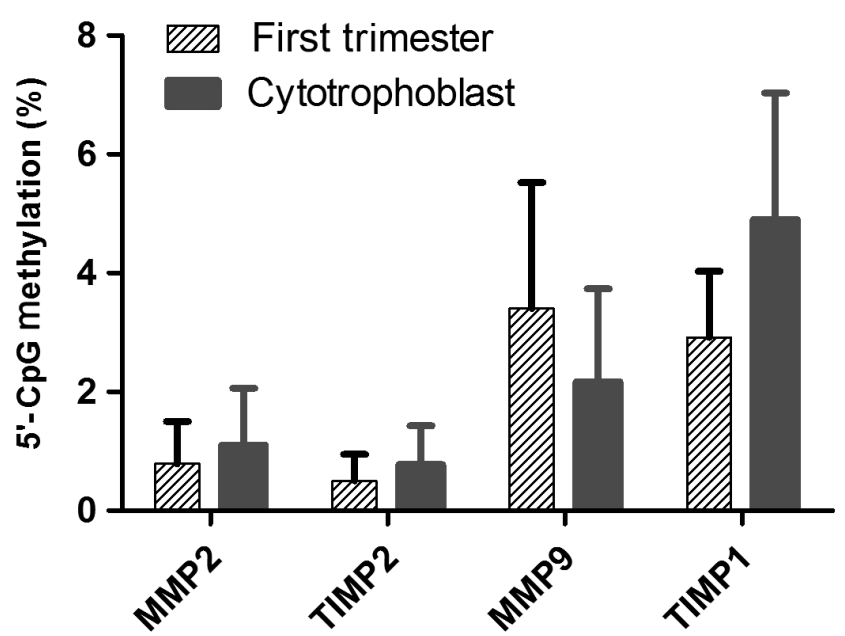

Figure 4 Promoter region DNA methylation for MMPS and TIMPS. Bar diagram to show \% CpG methylation at promoter regions of MMP2 and MMP9 and TIMP2 and TIMP1 in isolated first-trimester cytotrophoblasts; $n=30$ per group.

\section{Histone trimethylation at the promoter regions of MMPs and their inhibitors}

In order to estimate the transcription regulatory effect of histone modifications, especially histone trimethylation at lysine 9 and 27, on MMP2 and MMP9 and TIMP2 and TIMP1, we quantified the levels of $\mathrm{H} 3 \mathrm{~K} 9 / \mathrm{K} 27 \mathrm{me} 3$ at their promoter regions in normal placental villi groups as well as preeclampsia and molar villi groups via chromatin immunoprecipitation (ChIP) assay (Fig. 5A and B). ChIP analysis detected some significant and reverse pattern of changes in the levels of $\mathrm{H} 3 \mathrm{~K} 9 / 27 \mathrm{me} 3$ with advancing gestation at MMP2 vs TIMP2 and MMP9 vs TIMP1 promoter regions. H3K9me3 and H3K27me3 levels were observed to be raised by 2.2 -fold $(P<0.01)$ and 2 -fold at $M M P 2$ promoter region and decreased by 1.2 - and 2.6 -folds $(P<0.05)$ at TIMP2 promoter region, respectively, in the third-trimester placental villi relative to normal first-trimester villi. Similarly, MMP9 promoter region revealed $1.2-$ and 4 -fold $(P<0.05)$ increase in $\mathrm{H} 3 \mathrm{~K} 9 \mathrm{me} 3$ and $\mathrm{H} 3 \mathrm{~K} 27 \mathrm{me} 3$ levels, respectively, whereas TIMP1 promoter region was observed to show 2.5- and 2.1-fold, $P<0.05$, decrease in $\mathrm{H} 3 \mathrm{~K} 9 \mathrm{me} 3$ and H3K27me3 levels, respectively, by full-term normal pregnancy. Development of preeclampsia was observed to be associated with $1.8-$ and 1.7 -fold $(P<0.05)$ increase in H3K9me3 levels at MMP2 and MMP9 promoter regions in relative to its control group. Molar placental villi also showed relatively higher levels of H3K9me3 at MMP2 (2.2-fold, $P<0.05)$ and TIMP2 (1.9-fold, $P<0.05)$ and H3K27me3 at TIMP1 (1.8-fold, $P<0.05)$ promoter regions, whereas $\mathrm{H} 3 \mathrm{~K} 9 \mathrm{me} 3$ levels were relatively lower in molar villi at MMP9 (1.5-fold, $P<0.01)$ promoter region, in comparison with normal first-trimester placental villi.

Multiple regression analysis was performed to analyze the effect of epigenetic regulation on differential mRNA expression of these genes in normal gestational placental villi groups and two placental disorders: preeclamptic and molar villi showed high regression coefficient between mRNA expression of MMP2, MMP9, and TIMP1 and their respective $\mathrm{H} 3 \mathrm{~K} 9 \mathrm{me} 3, \mathrm{H} 3 \mathrm{~K} 27 \mathrm{me} 3$, and promoter region DNA methylation levels $\left(r^{2}=0.84\right.$, 0.92 and 0.93 , respectively) (Table 4).

\section{Discussion}

This study shows the importance of proper balance between MMP2 and MMP9 and their inhibitors TIMP2 and TIMP1 through the epigenetic regulation in maintaining normal pregnancy. The invasion and migration of trophoblasts into maternal uterus and degradation of the components of ECM resembles the growth of malignant tumors. These invasive properties of placental trophoblasts (Librach et al. 1991) and metastatic phenotype of cancer cells (Bernhard et al. 1994, Gokaslan et al. 1998) have been associated with 


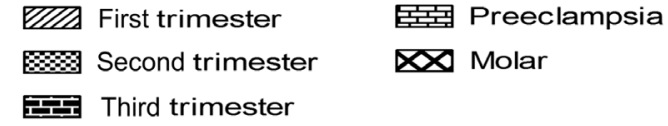

A

$\underline{M M P 2}$

$\underline{\text { TIMP1 }}$

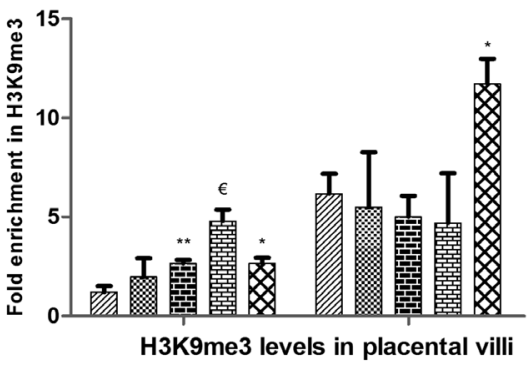

B

BMP2

TIMP1

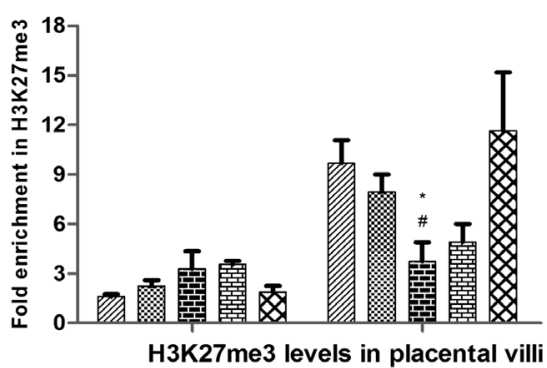

$\underline{M M P 9}$

TIMP1

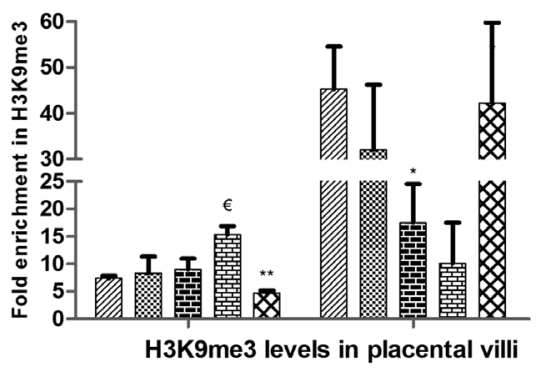

MMP9

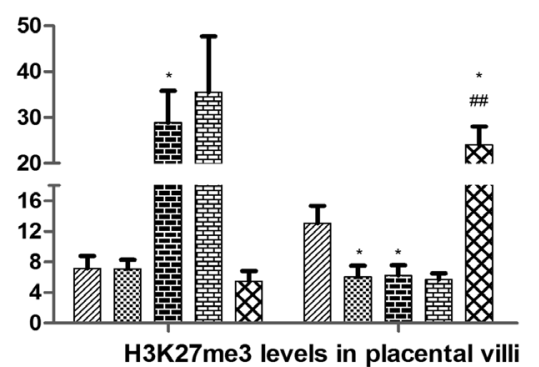

Figure 5 Quantification of histone modifications at promoter regions of MMPs and TIMPs among placental villous groups. Fold enrichment relative to non-specific IgG acting as negative control and normalized with input DNA in (A) $\mathrm{H} 3 \mathrm{~K} 9 \mathrm{me} 3$ and (B) $\mathrm{H} 3 \mathrm{~K} 27 \mathrm{me} 3$. The data are presented as mean of the observed fold change \pm S.E.M.; $n=4$ per group. $* P<0.05, * * P<0.01$ vs first trimester, ${ }^{\sharp} P<0.05,{ }^{\sharp \#} P<0.01$ vs second trimester, ${ }^{\epsilon} P<0.05$ vs third trimester. the activity of MMPs, whereas the inhibition of metastasis correlates with the action of TIMPs (DeClerck et al. 1992). Thus, the precise balance between the levels of MMPs and TIMPs regulate these pathways (Gomez et al. 1997). In light of the current literature, we analyzed the differential expression and the epigenetic regulation of MMPs and TIMPs, mediated by promoter region DNA methylation and histone trimethylation.

Our data revealed decreased expressions of MMP2 and MMP9 with advancing gestation, associated with reduced invasive potential of trophoblats, supporting an earlier study showing the role and MMP9 in the invasiveness of cultured cytotrophoblasts in Matrigel (Fisher et al. 1989). Further, the observed reverse trend in the expressions of TIMP2 and TIMP1, respective inhibitors of MMP2 and $M M P 9$, suggests effective high activity of these MMPs in early placental villi, supported by the reported highest activity of MMP9 in the first trimester of gestation (Librach et al. 1991, Cross et al. 1994).

Estimation of DNA methylation revealed hypomethylation at the promoter regions of MMP2 and MMP9 in placental villi, suggesting a similar role of DNA hypomethylation in activating expression of these invasion-promoting genes in placental tissue, as observed in the cancerous tissue (Shukeir et al. 2006, Farias et al. 2012). Emerging evidences suggest a significant role of chromatin-remodeling complexes in regulating expression of MMPs (Yan et al. 2003, Chang et al. 2006). In this context, we studied the involvement of histone trimethylation in regulating the expression of MMP expression in the placenta. Our data suggested the association of increased H3K9/K27me3 with decreased mRNA levels of MMP2 and MMP9 and decreased H3K9/K27me3 with increased mRNA levels of their inhibitors TIMP2 and TIMP1, with advancing gestation, relative to the first trimester. Thus, the reverse trends of $\mathrm{H} 3 \mathrm{~K} 9 / 27 \mathrm{me} 3$ levels at the promoters of MMPs and their inhibitors (TIMPs) might be regulating the observed reverse trends in their mRNA expressions during normal gestation. Our study is the first to show the role of histone modifications in regulating the expression of MMPs/TIMPs and thus supports the recently reported alteration in the expression levels of MMPs/TIMPs, upon use of chromatin-modifying agents (Vincent et al. 2015).

Deregulation in the invasive behavior of placental trophoblasts leads to the development of abnormal pregnancies such as GTDs (Hui et al. 2005) and preeclampsia (Brosens et al. 1972). Development of molar pregnancy and choriocarcinoma was found to be associated with abnormally high expression levels of MMP2 and MMP9 and low expression levels of TIMP2 and TIMP1, suggesting the association of raised MMPs: TIMPs ratio with the abnormal trophoblastic invasiveness observed in these disorders. Such a phenomenon is also observed in metastatic cancers (Nuovo et al. 
Table 4 Pearson correlation and multiple regression analysis for MMP2 and MMP9 and TIMP2 and TIMP1 in all five placental villous groups.

\begin{tabular}{|c|c|c|c|c|}
\hline \multirow[b]{2}{*}{ Gene } & \multicolumn{3}{|c|}{$r$} & \multirow{2}{*}{$\begin{array}{c}\text { Multiple regression analysis with } \\
\text { mRNA expression as dependent } \\
\text { variable: } r^{2} \text { (SEM) }\end{array}$} \\
\hline & $\mathrm{H} 3 \mathrm{~K} 9 \mathrm{me} 3$ & $\mathrm{H} 3 \mathrm{~K} 27 \mathrm{me} 3$ & $\begin{array}{c}\text { mRNA vs DNA } \\
\text { methylation }\end{array}$ & \\
\hline$M M P 2$ & & & 0.45 & $0.84(0.01)$ \\
\hline mRNA & -0.4 & -0.77 & & \\
\hline DNA methylation & 0.45 & 0.04 & & \\
\hline TIMP2 & & & ND & $0.56(0.03)$ \\
\hline mRNA & -0.53 & -0.73 & & \\
\hline DNA methylation & UD & UD & & \\
\hline MMP9 & & & 0.76 & $0.92(0.001)$ \\
\hline mRNA & -0.72 & -0.62 & & \\
\hline DNA methylation & -0.2 & -0.14 & & \\
\hline TIMP1 & & & 0.3 & $0.93(0.008)$ \\
\hline mRNA & $-0.9^{*}$ & $-0.85^{*}$ & & \\
\hline DNA methylation & -0.2 & 0.03 & & \\
\hline
\end{tabular}

$r$, Pearson's coefficient, $r^{2}$, regression determination coefficient, S.E.M., standard error of measurement, ND, not determined due to unmethylated gene promoter. "Equation for Prediction for each gene was 'mRNA expression $=\beta 1 \mathrm{H} 3 \mathrm{~K} 9 \mathrm{me} 3+\beta 2 \mathrm{H} 3 \mathrm{~K} 27 \mathrm{me} 3+\beta 3 \mathrm{DNA}$ methylation $+\alpha$ ', where $\beta 1, \beta 2, \beta 3$ are regression coefficients and $\alpha$ is intercept of test. $* P<0.05$.

1995). Our findings are in accordance with the earlier studies correlating high expression of MMPs to the high invasiveness in GTDs (Singh et al. 2011) and inverse correlation between invasiveness of human cells and the levels of TIMPs (Hicks et al. 1984). Decreased levels of $\mathrm{H} 3 \mathrm{~K} 9 \mathrm{me} 3$ at $M M P 9$ and increased levels of $\mathrm{H} 3 \mathrm{~K} 9 \mathrm{me} 3$ at TIMP1 and both H3K9/27me3 at TIMP2 were detected in molar villi, relative to early trimester normal villi. The association of such changes in $\mathrm{H} 3$ trimethylation levels and mRNA expression of these genes were also supported by observed higher Pearson's correlation in our study. Therefore, these observations emphasize the role of aberrant trimethylation at $\mathrm{H} 3 \mathrm{~K} 9 / \mathrm{K} 27$ in the pathology of molar pregnancy. Aberrant histone modifications at the promoter regions of MMPs are also reported to be involved in the pathogenesis of other diseases such as skin disorders and diabetic retinopathy (Kim et al. 2009, Zhong \& Kowluru 2013). Silencing of TIMPs via promoter methylation is a prominent feature of cancer cells and such DNA methylation-mediated repression of gene expression was observed for TIMP1 in choriocarcinoma cell line (JEG-3 cells) (Yuan et al. 2004). Notably, JEG-3 cells revealed hypermethylation at the promoter regions of MMP2 and MMP9. However, it was not found to down-regulate the expression levels of these genes, whereas a positive Pearson's correlation coefficient was observed between mRNA expression and the respective promoter region DNA methylation of MMP2 and MMP9. Similar examples of the up-regulation of hypermethylated genes have been cited earlier as well (Jones 1999, Renner et al. 2013). The transcriptional regulation of such overexpressed and hypermethylated genes can be either independent of DNA methylation or promoter hypermethylation might be affecting gene transcription via some different epigenetic mechanisms (Jones \& Baylin 2007). Furthermore, high methylation was in fact found to be correlated with enhanced invasiveness. Such a correlation has been reported previously for placental first-trimester explants, where increased methylation of MMP2 was found to be associated with high invasiveness of these explants (van Dijk et al. 2012).

Shallow interstitial invasion and limited endovascular invasion by trophoblasts have been associated with the pathogenesis of preeclampsia (Norwitz et al. 2001). In this study, the development of preeclampsia was found to be associated with deregulation in the levels of $\mathrm{H} 3 \mathrm{~K} 9 / 27 \mathrm{me} 3$, showing increased levels of $\mathrm{H} 3 \mathrm{~K} 9 \mathrm{me} 3$ and both $\mathrm{H} 3 \mathrm{~K} 9 / 27 \mathrm{me} 3$ associated with low expression of $M M P 2$ and $M M P 9$ respectively. These results support the documented deficient expression of MMP2 and MMP9, in preeclampsia (Lockwood et al. 2008, Zhang et al. 2011). MMPs also play important role in controlling the bioactivity of growth factors, angiogenic factors, cytokines (Staun-Ram \& Shalev 2005), and release of VEGF (Monaco et al. 2006), thus their deficient expression in preeclampsia might also be hampering the $V E G F$ release, as supported by lower levels of VEGF reported in preeclampsia (Levine et al. 2004). Hence, these factors might be contributing to poor migration and proliferation of the endothelial cells and poor development of new blood vessels. The observed high expression of MMP2 in maternal blood in preeclampsia is consistent with the documented high level of MMP2 in preeclamptic plasma (Myers et al. 2005) and might have a role in regulating vascular tone, as highlighted by a recent study that suggested the role of MMP1 expression in vasoconstriction (Mousa et al. 2012). Consistent with our results, high levels of TIMP1 and TIMP2 have been demonstrated in preeclamptic endothelial cells (Merchant et al. 2004). High expression levels of TIMP2 and TIMP1 in preeclampsia might be further decreasing the activities of already compromised levels of MMP2 and $M M P 1$, respectively, hence leading to decreased invasion of uterine vasculature. Thus, the reported decrease in the invasive potential of JAR cells after their treatment with preeclamptic serum (Mahameed et al. 2005) might be due to high levels of TIMPs present in preeclamptic 
serum. Overexpression of TIMP1 and TIMP2 is known to reduce tumor growth (Bai et al. 2005), and keeping in view the homology between normal placentation and tumor growth, it can be commented that their increased expression might also be contributing to the specific phenotype of preeclampsia involving intrauterine growth retardation and lighter placentas.

Significantly higher expressions of MMPs and TIMPs except TIMP1, in placental villi with reference to their respective maternal blood, support the role and importance of these genes in placental invasiveness. Relative lower expression of TIMP1 in first-trimester and molar placental villi with respect to their corresponding maternal blood might be associated with the minimum inhibition of MMP9 in these placental tissues.

Our study analyzed the role of only H3K9/27me3, as we aimed to study the effect of transcription-repressing epigenetic mechanisms such as DNA methylation and histone trimethylation; however, future study can be carried out to analyze the role of transcription-enhancing histone modifications such as histone acetylation to provide more insight into the role of various histone modifications on the differential expression of MMPs/ TIMPs during placentation. Moreover, this study has only analyzed the mRNA expression of MMPs irrespective of their activity, as we intended to access gene regulation at the DNA level.

\section{Conclusion}

In light of our results, we suggest the role of balanced expression of MMPs and their respective TIMPs, mediated by $\mathrm{H} 3 \mathrm{~K} 9 / 27 \mathrm{me} 3$, as the strong regulatory factor for maintaining normal pregnancy and the deregulation of these modifications associated with abnormal expression of MMPs and their respective TIMPs, involved in the development of placental disorders such as preeclampsia and hydatidiform mole. The observed aberrations in histone modifications and the changes induced in mRNA expression of MMPs and their TIMPs can be further evaluated for their potential as targets to design therapeutic strategies for pregnancyrelated disorders.

\section{Declaration of interest}

The authors declare that there is no conflict of interest that could be perceived as prejudicing the impartiality of the research reported.

\section{Funding}

This work has been supported by Indian Council of Medical Education and Research (ICMR 5/10/FR/3/2010-RHN).

\section{Acknowledgement}

The authors would like to thank the enrolled pregnant women for making this study possible.

\section{References}

Bai SX, Wang YL, Qin L, Xiao ZJ, Herva R \& Piao YS 2005 Dynamic expression of matrix metalloproteinases (MMP2, 9 and 14) and the tissue inhibitors of MMPs (TIMP1, 2 and 3) at the implantation site during tubal pregnancy. Reproduction 129 103-113. (doi:10.1530/ rep.1.00283)

Bernhard EJ, Gruber SB \& Muschel RJ 1994 Direct evidence linking expression of matrix metalloproteinase 9 (92-kDa gelatinase/collagenase) to the metastatic phenotype in transformed rat embryo cells. PNAS 91 4293-4297. (doi:10.1073/pnas.91.10.4293)

Brosens IA, Robertson WB \& Dixon HG 1972 The role of the spiral arteries in the pathogenesis of preeclampsia. Obstetrics and Gynecology Annual 1 177-191.

Chang S, Young BD, Li S, Qi X, Richardson JA \& Olson EN 2006 Histone deacetylase 7 maintains vascular integrity by repressing matrix metalloproteinase 10. Cell 126 321-334. (doi:10.1016/j. cell.2006.05.040)

Chiu RW, Poon LL, Lau TK, Leung TN, Wong EM \& Lo YM 2001 Effects of blood-processing protocols on fetal and total DNA quantification in maternal plasma. Clinical Chemistry 47 1607-1613.

Corthorn J, Rey S, Chacon C \& Valdes G 2007 Spatio-temporal expression of MMP2, MMP9 and tissue kallikrein in uteroplacental units of the pregnant guinea-pig (Cavia porcellus). Reproductive Biology and Endocrinology 5 27. (doi:10.1186/1477-7827-5-27)

Cross JC, Werb Z \& Fisher SJ 1994 Implantation and the placenta: key pieces of the development puzzle. Science 266 1508-1518. (doi:10.1126/science.7985020)

DeClerck YA, Perez N, Shimada H, Boone TC, Langley KE \& Taylor SM 1992 Inhibition of invasion and metastasis in cells transfected with an inhibitor of metalloproteinases. Cancer Research 52 701-708.

Dokras A, Coffin J, Field L, Frakes A, Lee H, Madan A, Nelson T, Ryu GY \& Yoon JG 2006 Epigenetic regulation of maspin expression in the human placenta. Molecular Human Reproduction 12 611-617. (doi:10.1093/ molehr/gal074)

Farias LC, Gomes CC, Rodrigues MC, de Castro WH, Lacerda JC, e Ferreira E \& Gomez RS 2012 Epigenetic regulation of matrix metalloproteinase expression in ameloblastoma. BMC Clinical Pathology 1211. (doi:10.1186/1472-6890-12-11)

Fisher SJ 2004 The placental problem: linking abnormal cytotrophoblast differentiation to the maternal symptoms of preeclampsia. Reproductive Biology and Endocrinology 2 53. (doi:10.1186/1477-7827-2-53)

Fisher SJ, Cui TY, Zhang L, Hartman L, Grahl K, Zhang GY, Tarpey J \& Damsky CH 1989 Adhesive and degradative properties of human placental cytotrophoblast cells in vitro. Journal of Cell Biology 109 891-902. (doi:10.1083/jcb.109.2.891)

Gokaslan ZL, Chintala SK, York JE, Boyapati V, Jasti S, Sawaya R, Fuller G, Wildrick DM, Nicolson GL \& Rao JS 1998 Expression and role of matrix metalloproteinases MMP2 and MMP9 in human spinal column tumors. Clinical \& Experimental Metastasis 16 721-728.

Gomez DE, Alonso DF, Yoshiji H \& Thorgeirsson UP 1997 Tissue inhibitors of metalloproteinases: structure, regulation and biological functions. European Journal of Cell Biology 74 111-122.

Hicks NJ, Ward RV \& Reynolds JJ 1984 A fibrosarcoma model derived from mouse embryo cells: growth properties and secretion of collagenase and metalloproteinase inhibitor (TIMP) by tumour cell lines. International Journal of Cancer 33 835-844. (doi:10.1002/(ISSN)1097-0215)

Hui P, Martel M \& Parkash V 2005 Gestational trophoblastic diseases: recent advances in histopathologic diagnosis and related genetic aspects. Advances in Anatomic Pathology 12 116-125. (doi:10.1097/01. pap.0000163960.11107.73)

Jones PA 1999 The DNA methylation paradox. Trends in Genetics 15 34-37. (doi:10.1016/S0168-9525(98)01636-9)

Jones PA \& Baylin SB 2007 The epigenomics of cancer. Cell 128 683-692. (doi:10.1016/j.cell.2007.01.029) 
Kim MK, Shin JM, Eun HC \& Chung JH 2009 The role of p300 histone acetyltransferase in UV-induced histone modifications and MMP1 gene transcription. PLOS ONE 4 e4864.

Levine RJ, Maynard SE, Qian C, Lim KH, England LJ, Yu KF, Schisterman EF, Thadhani R, Sachs BP, Epstein FH et al. 2004 Circulating angiogenic factors and the risk of preeclampsia. New England Journal of Medicine 350 672-683. (doi:10.1056/NEJMoa031884)

Librach CL, Werb Z, Fitzgerald ML, Chiu K, Corwin NM, Esteves RA, Grobelny D, Galardy R, Damsky CH \& Fisher SJ 1991 92-kD type IV collagenase mediates invasion of human cytotrophoblasts. Journal of Cell Biology 113 437-449. (doi:10.1083/jcb.113.2.437)

Livak KJ \& Schmittgen TD 2001 Analysis of relative gene expression data using real-time quantitative PCR and the 2(-Delta Delta C(T)) Method. Methods 25 402-408. (doi:10.1006/meth.2001.1262)

Lockwood CJ, Oner C, Uz YH, Kayisli UA, Huang SJ, Buchwalder LF, Murk W, Funai EF \& Schatz F 2008 Matrix metalloproteinase 9 (MMP9) expression in preeclamptic decidua and MMP9 induction by tumor necrosis factor alpha and interleukin 1 beta in human first trimester decidual cells. Biology of Reproduction 78 1064-1072. (doi:10.1095/ biolreprod.107.063743)

Mahameed S, Goldman S, Gabarin D, Weiss A \& Shalev E 2005 The effect of serum from women with preeclampsia on JAR (trophoblast-like) cell line. Journal of the Society for Gynecologic Investigation 12 e45-e50.

Merchant SJ, Narumiya H, Zhang Y, Guilbert LJ \& Davidge ST 2004 The effects of preeclampsia and oxygen environment on endothelial release of matrix metalloproteinase-2. Hypertension in Pregnancy 23 47-60. (doi:10.1081/PRG-120028281)

Monaco S, Sparano V, Gioia M, Sbardella D, Di Pierro D, Marini S \& Coletta M 2006 Enzymatic processing of collagen IV by MMP2 (gelatinase A) affects neutrophil migration and it is modulated by extracatalytic domains. Protein Science 15 2805-2815. (doi:10.1110/ (ISSN)1469-896X)

Mousa AA, Cappello RE, Estrada-Gutierrez G, Shukla J, Romero R, Strauss JF 3rd \& Walsh SW 2012 Preeclampsia is associated with alterations in DNA methylation of genes involved in collagen metabolism. American Journal of Pathology 181 1455-1463. (doi:10.1016/j. ajpath.2012.06.019)

Myers JE, Merchant SJ, Macleod M, Mires GJ, Baker PN \& Davidge ST 2005 MMP2 levels are elevated in the plasma of women who subsequently develop preeclampsia. Hypertension in Pregnancy 24 103-115. (doi:10.1081/PRG-200059836)

Nagase H, Visse R \& Murphy G 2006 Structure and function of matrix metalloproteinases and TIMPs. Cardiovascular Research 69 562-573. (doi:10.1016/j.cardiores.2005.12.002)

Nagase H \& Woessner JF Jr 1999 Matrix metalloproteinases. Journal of Biological Chemistry 27421491-21494. (doi:10.1074/jbc.274.31.21491)

Norwitz ER, Schust DJ \& Fisher SJ 2001 Implantation and the survival of early pregnancy. New England Journal of Medicine 345 1400-1408. (doi:10.1056/NEJMra000763)

Nuovo GJ, MacConnell PB, Simsir A, Valea F \& French DL 1995 Correlation of the in situ detection of polymerase chain reactionamplified metalloproteinase complementary DNAs and their inhibitors with prognosis in cervical carcinoma. Cancer Research 55 267-275.

Pijnenborg R, Robertson WB, Brosens I \& Dixon G 1981 Review article: trophoblast invasion and the establishment of haemochorial placentation in man and laboratory animals. Placenta 2 71-91. (doi:10.1016/S01434004(81)80042-2)

Rahat B, Hamid A, Ahmad Najar R, Bagga R \& Kaur J 2014 Epigenetic mechanisms regulate placental $\mathrm{c}$-myc and hTERT in normal and pathological pregnancies; c-myc as a novel fetal DNA epigenetic marker for pre-eclampsia. Molecular Human Reproduction 20 1026-1040. (doi:10.1093/molehr/gau053)
Rahnama F, Shafiei F, Gluckman PD, Mitchell MD \& Lobie PE 2006 Epigenetic regulation of human trophoblastic cell migration and invasion. Endocrinology 147 5275-5283. (doi:10.1210/en.2006-0288)

Renner M, Wolf T, Meyer H, Hartmann W, Penzel R, Ulrich A, Lehner B, Hovestadt V, Czwan E, Egerer G et al. 2013 Integrative DNA methylation and gene expression analysis in high-grade soft tissue sarcomas. Genome Biology 14 r137.

Seval Y, Akkoyunlu G, Demir R \& Asar M 2004 Distribution patterns of matrix metalloproteinase (MMP)2 and 9 and their inhibitors (TIMP1 and TIMP2) in the human decidua during early pregnancy. Acta Histochemica 106 353-362. (doi:10.1016/j.acthis.2004.07.005)

Shukeir N, Pakneshan P, Chen G, Szyf M \& Rabbani SA 2006 Alteration of the methylation status of tumor-promoting genes decreases prostate cancer cell invasiveness and tumorigenesis in vitro and in vivo. Cancer Research 66 9202-9210. (doi:10.1158/0008-5472.CAN-06-1954)

Singh M, Kindelberger D, Nagymanyoki Z, Ng SW, Quick CM, Elias KM, Yamamoto H, Fichorova R, Fulop V \& Berkowitz RS 2011 Matrix metalloproteinases and their inhibitors and inducer in gestational trophoblastic diseases and normal placenta. Gynecologic Oncology 122 178-182. (doi:10.1016/j.ygyno.2011.03.025)

Soundararajan R \& Rao AJ 2004 Trophoblast 'pseudo-tumorigenesis': significance and contributory factors. Reproductive Biology and Endocrinology 2 15. (doi:10.1186/1477-7827-2-15)

Staun-Ram E \& Shalev E 2005 Human trophoblast function during the implantation process. Reproductive Biology and Endocrinology 356. (doi:10.1186/1477-7827-3-56)

van Dijk M, Visser A, Posthuma J, Poutsma A \& Oudejans CB 2012 Naturally occurring variation in trophoblast invasion as a source of novel (epigenetic) biomarkers. Frontiers in Genetics 322.

Verma RP \& Hansch C 2007 Matrix metalloproteinases (MMPs): chemicalbiological functions and (Q)SARs. Bioorganic \& Medicinal Chemistry 15 2223-2268.

Vincent ZL, Mitchell MD \& Ponnampalam AP 2015 Regulation of MT1MMP/MMP2/TIMP2 axis in human placenta. Journal of Inflammation Research 8 193-200. (doi:10.2147/JIR)

Visse R \& Nagase H 2003 Matrix metalloproteinases and tissue inhibitors of metalloproteinases: structure, function, and biochemistry. Circulation Research 92 827-839. (doi:10.1161/01.RES.0000070112.80711.3D)

Yan C, Wang H, Toh Y \& Boyd DD 2003 Repression of 92-kDa type IV collagenase expression by MTA1 is mediated through direct interactions with the promoter via a mechanism, which is both dependent on and independent of histone deacetylation. Journal of Biological Chemistry 278 2309-2316. (doi:10.1074/jbc.M210369200)

Yuan BZ, Jefferson AM, Popescu NC \& Reynolds SH 2004 Aberrant gene expression in human non small cell lung carcinoma cells exposed to demethylating agent 5-aza-2'-deoxycytidine. Neoplasia 6 412-419. (doi:10.1593/neo.03490)

Zhang H, Long Q, Ling L, Gao A, Li H \& Lin Q 2011 Elevated expression of KiSS-1 in placenta of preeclampsia and its effect on trophoblast. Reproductive Biology 11 99-115. (doi:10.1016/S1642$431 \times(12) 60048-5)$

Zhong Q \& Kowluru RA 2013 Regulation of matrix metalloproteinase-9 by epigenetic modifications and the development of diabetic retinopathy. Diabetes 62 2559-2568. (doi:10.2337/db12-1141)

Received 2 February 2016

First decision 7 March 2016

Revised manuscript received 5 April 2016

Accepted 7 April 2016 